\title{
A profile of Stephanie Pain, associate editor of New Scientist
}

n 1992, the team working with data collected by NASA's Cosmic Background Explorer (COBE) satellite made headlines around the world when they announced they had found tiny fluctuations - the seeds of today's galaxies - in the cosmic microwave background radiation. Stephen Hawkins hailed the findings as the discovery of the century, while headlines such as "ripples at the edge of the Universe" fired the popular imagination.

New Scientist was not immune from the excitement. The story broke on a Friday and was the main topic of conversation that evening in the wine bar. Stephanie Pain, then the magazine's news editor, became convinced that they should discard the planned cover - something that New Scientist has done only rarely - and replace it with an image related to the COBE story.

At $11 \mathrm{pm}$ she rang the publisher and succeeded in convincing her to make the switch. Over the weekend, they scrambled for a new cover. At the same time the magazine's astronomy consultant, Nigel Henbest, set about getting every detail of the story. On Monday morning he sat down to write 2,000 words explaining the results and their significance. "It was brilliant," says Pain. "It shows what you can do when you have people who know what they are doing."

Pain was New Scientist's news editor for six years, but it was not the job she envisaged for herself either when she was an undergraduate or when studying for a $\mathrm{PhD}$. "As an undergraduate I though vaguely about being a biologist without really knowing what that was. Then when I graduated I knew I didn't want to do research or to teach."

Instead, Pain became a lexicographer. A stint as a desk editor for medical publications followed, but after two years of this she had learned all she wanted to about handling manuscripts for publication, and she began combing the advertisements for new opportunities. One of the things that Pain, like many others, says frequently is "I didn't expect to get the job". So when she spotted an opening for a research assistant in the oceanography department at Swansea University she sent off her application with magine, I have a

background in

oceanography and

have had a chance to

visit the great marine

laboratories like Woods

Hole and Scripps — and

get paid for writing about

it. I can't think of anything else l'd rather do

little hope. She was particularly conscious that she was not a marine biologist.

Nevertheless, Pain was soon ensconced in Wales studying for a $\mathrm{PhD}$ as part of a research team investigating whether deep oceans experience seasonal variations. The question was new at the time, although the field has since moved on and firmly established that there are such variations. Pain's piece of the puzzle was to investigate whether there was a pattern to starfish reproduction that might reflect seasonal variations. "Being locked up in a ship in bad weather is good training for being on the news desk in a crisis," she says.

Three years after starting her research, Pain had written her thesis and was faced yet again with the question of how to earn a living. Until now she had been opportunistic, responding to what seemed interesting. "For the first time, I thought carefully about the future. I had colleagues in their 40s on their third or fourth postdoc. I probably could have chased funds for more research, but I could see myself at 40 without a full-time job."

Instead, she left academic research and unwittingly mounted a roller coaster. She freelanced while job hunting, then got work as a medical editor, and was made redundant after three months. She saw an advertisement for a job at New Scientist, applied, and then had to sit back and wait because the editors of the magazine promptly went on strike. Once again, she did not think she would get the job. Once again, she did.

Pain started as the magazine's book review editor, then became successively the science news editor, life sciences editor,

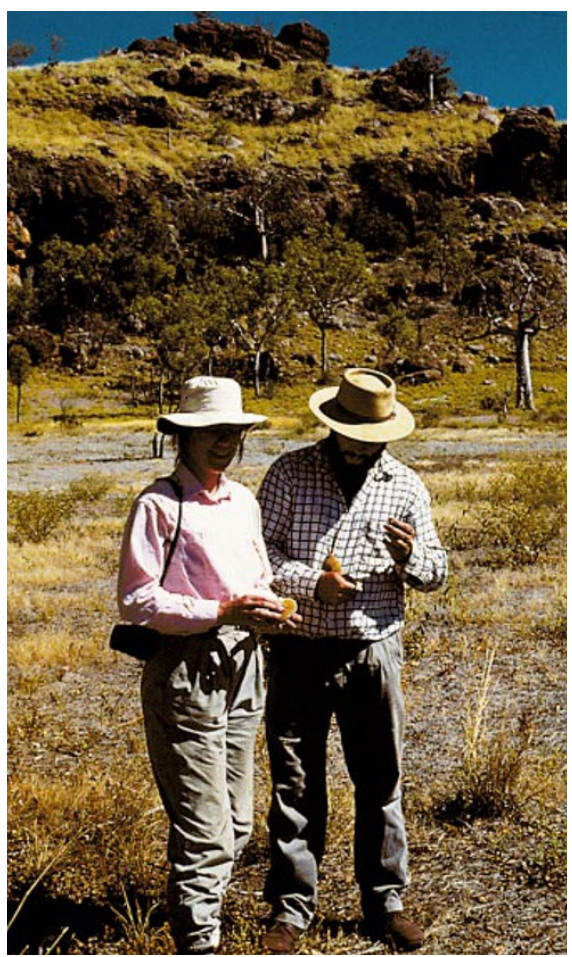

Pain relishes the opportunities her job throws up, here on expedition in the Australian bush.

deputy features editor and news editor. She is now the associate editor and is a free-roving editor writing about subjects that interest her. Research, she says, taught her to be observant and careful, traits which have helped her career.

Clearly she loves her life as a science journalist and has enjoyed her career to date, but does she miss scientific research? "Now and again," says Pain. "When I'm deep into the research for a feature and I see a problem and think I'd like to solve that. But the feeling goes when I finish the feature."

And there are compensations. For example, travelling with the Royal Geographical Society in the Australian bush and writing features about their work, spending a week at a wildlife forensic laboratory in Oregon or snorkelling on the great barrier reef. "I've been given fantastic opportunities," says Pain. "Imagine, I have a background in oceanography and have had a chance to visit the great marine laboratories like Woods Hole and Scripps - and get paid for writing about it. I can't think of anything else I'd rather do." 